\title{
HYDROCYANIC ACID AND SUGAR CONTENT DYNAMICS UNDER NITROGEN AND SULPHUR APPLICATION TO FORAGE SORGHUM CULTIVARS
}

\author{
Ahmad SHER $I^{*}$, Muhammad ANSAR ${ }^{2}$, Abdul MANAF ${ }^{2}$, Abdul QAYYUM ${ }^{3}$, Muhammad Farhan SAEED \\ and Muhammad IRFAN ${ }^{2}$ \\ ${ }^{1}$ College of Agriculture, Bahauddin Zakariya University, Bahadur Campus Layyah, Pakistan \\ ${ }^{2}$ Department of Agronomy, PMAS-Arid Agriculture University Rawalpindi, Pakistan \\ ${ }^{3}$ Department of Agriculture, University of Haripur, 22620, Pakistan \\ *Corresponding author: ahmad_sher786@yahoo.com
}

Recieved : 25.09.2013

\begin{abstract}
Sorghum crop provides excellent forage in dry land areas. It has ability to tolerate high temperature and grow under minimal soil moisture. Sugar content in Sorghum is of prime importance regarding, animal feed value as well as biofuel production. However, high level of HCN toxin production is a serious problem associated with this crop which could be lethal to animals if ingested in greater quantities. In this study hydrocyanic acid and sugar content dynamics were determined on two forage sorghum cultivars i.e. JS-2002 and Chakwal sorghum at different developmental stages (booting ${ }^{a}$ and $50 \%$ heading $\left.{ }^{b}\right)$. Fertilizer treatments of nitrogen $(0$, 60 and $\left.120 \mathrm{~kg} \mathrm{ha}^{-1}\right)$ and sulphur levels $\left(0,20\right.$ and $\left.40 \mathrm{~kg} \mathrm{ha}^{-1}\right)$ were applied in replicates. The experiment was arranged in randomized complete block design. The results clearly depicted that increase in nitrogen levels gradually increased the $\mathrm{HCN}$ and sugar contents irrespective to sulphur and delayed harvesting times. Increase in $\mathrm{HCN}\left(21^{\mathrm{a}} \& 22^{\mathrm{b}} \%\right)$ and brix value $\left(56^{\mathrm{a}} \& 59^{\mathrm{b}} \%\right)$ was found more at $120 \mathrm{~kg} \mathrm{~N} \mathrm{ha}^{-1}$ when compared with $0 \mathrm{~kg} \mathrm{~N} \mathrm{ha}^{-1}$ (control) treatment. Similarly increase in sulphur application caused increase in brix value however; inverse relationship with HCN content was recorded. Results also indicated that sorghum cultivar JS-2002 produced $27^{\mathrm{a}} \& 40^{\mathrm{b}} \%$ decline in $\mathrm{HCN}$ content while $8^{\mathrm{a}} \& 18^{\mathrm{b}} \%$ more sugar content when compared with Chakwal sorghum. Seasonal variations resulted maximum sugar production of 14.9, 25.6\% and HCN content of $21.9 \& 13.1 \mathrm{mg} / 100 \mathrm{~g}$ during different year time $(2010$ and 2009 when compared with 2008 , respectively) probably due to variation in seasonal rainfall. Three years field study indicate that JS-2002 produced less HCN with low dose of $N$ application $\left(0 \mathrm{~kg} \mathrm{ha}^{-1}\right)$ and higher application of sulphur $\left(40 \mathrm{~kg} \mathrm{ha}^{-1}\right)$ while more brix value at $40 \mathrm{~kg} \mathrm{~S}$ and $120 \mathrm{~kg} \mathrm{~N} \mathrm{ha}^{-1}$ under sub-tropical rainfed conditions.
\end{abstract}

Keywords: Brix value, HCN, nitrogen, sorghum cultivars, sub-tropical condition, sulphur

\section{INTRODUCTION}

Sorghum is one of the important summer fodder crops all over the country particularly in rainfed regions. It is nutritious, juicy, palatable and well-liked by the cattle. Because of its high tolerance to various stresses, it is extensively grown as a major source of fodder preferred over maize (Reddy et al., 2004). Sorghum plants contain a cyanogenic glycoside called dhurrin. According to Lang (2001) when the plants cells damaged (insect attack, crust, hailing, frost injury), the available cyanogenic glycoside (dhurrin) is hydrolyzed by making two fermentation enzymes (Ac/ac and $\mathrm{Li} / \mathrm{li}$ ) which converted into hydrocyanic acid $(\mathrm{HCN})$. Cyanogenesis is a character which genetically controlled, but it is often affected by different biotic and abiotic factors (Pederson et al., 1996). The main factors responsible for $\mathrm{HCN}$ accumulation are plant species (Sudan grass have less HCN contents than sorghum), plant organs (leaves have higher $\mathrm{HCN}$ contents than other parts), suckers (tillers have more $\mathrm{HCN}$ potential), fertilizer (unevenness nitrogen and phosphorus in the soil causes the $\mathrm{HCN}$ contents to increase) and drought (dryland sorghum has more $\mathrm{HCN}$ contents than irrigated one due to water stress).

The available amount of cyanide poisoning in forage is important to consider for animal's physiological conditions. On the wet weight basis if $\mathrm{HCN}$ level in forage sorghum exceed $200 \mathrm{mg} \mathrm{kg}^{-1}$ is harmful for livestock (Fjell et al., 1991).

No doubt nitrogen application is considered essential for efficient plant growth and cell division (Duli et al., 2005; Saraswathy et al., 2007). However, higher level of nitrogen application may increase $\mathrm{HCN}$ contents of forage sorghum and thus poisoning animals (Aziz and AbdelGwad, 2008). Application of nitrogen fertilizer also increases brix value (Pholsen and Sornsungnoen, 
2004). Different growth stages of sorghum produce varying levels of sugar in stem quantitatively and qualitatively specifically maximum sugar content are accumulated at maturity stage (Parvatikar and Manjunath, 1991). Nitrogen fertilizer promotes sucrose content, protein percent and growth rate in sweet sorghum (Tsialtas and Maslaris, 2005).

Sulphur is an essential element of nutrition for plant and animal whose deficiencies have been increasing throughout the world (Platou and Irish, 1982). The use of S-free mineral fertilizers has created widespread deficiency of Sin soils (Chaubey et al., 1992). Sulphur fertilization can increase the yield and the quality of forages in the areas of S deficient soils (Puoli et al., 1991; Hallmark and Brown, 1994). Moreover, S fertilization is known to improve nitrogen $(\mathrm{N})$ utilization efficiency by the crops (Schnug and Haneklaus, 1993).

Most of the scientific work had focused on nitrogen but little attention had been paid to sulphur. Keeping in view this scenario, the present study was undertaken to explore the hydrocyanic acid and sugar content dynamics under nitrogen and sulphur application to forage sorghum cultivars sown under sub-tropical dryland conditions of Pakistan.

\section{MATERIALS AND METHODS}

Experiment was carried out at University Research Farm (URF) Chakwal Road (33 56' N, 72 ${ }^{\circ} 52^{\prime}$ E, 498 m a.s.l.) , PMAS- Arid Agriculture University Rawalpindi, during 2008, 2009 and 2010 to determine the hydrocyanic acid and sugar content dynamics with varying nitrogen and sulphur application to forage sorghum cultivars. The treatments consisted of two forage sorghum cultivars i.e. JS-2002 and Chakwal sorghum were sown with each three nitrogen levels $\left(0,60\right.$ and $\left.120 \mathrm{~kg} \mathrm{ha}^{-1}\right)$ in the form of urea and sulphur levels (0, 20 and $\left.40 \mathrm{~kg} \mathrm{ha}^{-1}\right)$ as gypsum arranged in randomized complete block design replicated four times.

Before sowing, soil sampling was carried out at two depths i.e. 0-15 and $15-30 \mathrm{~cm}$ from experimental site for physico-chemical properties. The soil was sandy-loam with $\mathrm{pH}$ about neutral. The total $\mathrm{N}$ content and organic matter were low, particularly in the lower layers of soil i.e. 15-30 cm. While phosphorus status (less than $5 \mathrm{mg} \mathrm{P} \mathrm{kg}^{-1}$ ) was observed (Olsen method): poor in both soil layers. Mean temperature $\left({ }^{\circ} \mathrm{C}\right)$, rainfall $(\mathrm{mm})$ and relative humidity (\%) data recorded during the study period is presented in Figure 1.

\section{Determination of total cyanide through spectrophotometer}

Leaf samples were chopped and ground with pestle and mortar. For calibration, a flat bottom plastic bottle with buffer of $\mathrm{pH} 6$ and round filter paper disc were loaded. Grinded leaf sample (100 mg) was taken in the transparent bottle and poured $1 \mathrm{~mL}$ phosphate buffer solution in it. A yellow picrate paper was attached with the plastic stripe to absorb the HCN vapors and the upper end of stripe is further attached in the center of bottle lid with the help of tape and hanged in the

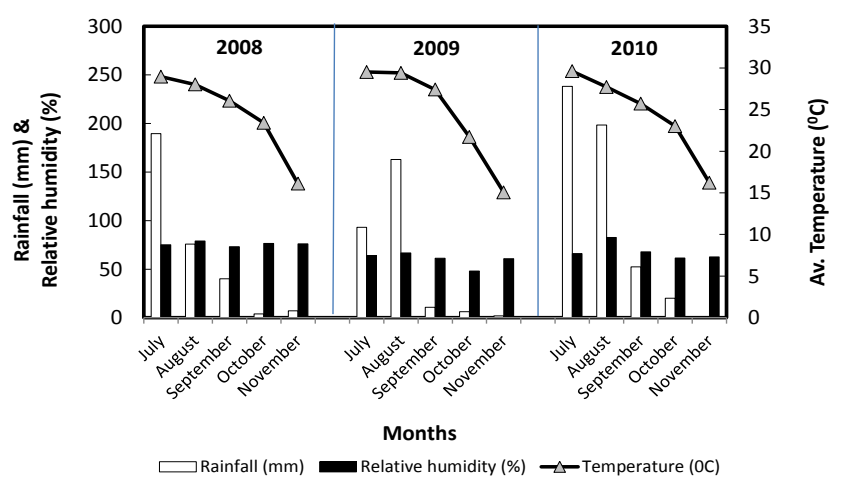

Figure 1. Rainfall, av. temperature and relative humidity recorded during crop growth period

bottle in such a way that picrate paper may not come in contact with liquid (leaf sample + buffer solution) lying in the bottom of bottle. A blank was also run having no leaves. Both the bottles were left for overnight at the room temperature. Next day the picrate paper was removed from plastic stripe cautiously. For about 30 minutes, the picrate paper was submerged into $5 \mathrm{~mL}$ distilled water with mild shaking. At $510 \mathrm{~nm}$ wavelength absorbance picrate solution was recorded by spectrophotometer as described by Bradbury et al. (1999). The hydrocyanic acid contents were calculated as under:

Total cyanide contents $\left(\mathrm{mg} \mathrm{kg}^{-1}\right)=396 \times$ absorbance reading.

\section{Sweetness (\%fresh stalk)}

Sugar content (brix value) of forage sorghum was determined with the help of a refractometer (hand held brix refractometer, Sino Technology, Fujian, China), by the method of Yun-long et al. (2006).

Five plants were selected at random from each plot. The juice from the main stalk of each plant was extracted by simply twisting the stem. The extract of all five stalks was mixed and $0.5 \mathrm{ml}$ of the mixed juice sample was applied to the automatic temperature compensating refractometer and the total sugar contents (as brix grades) were determined.

The HCN leaf content and sugar content were recorded at two growth stages viz. booting and $50 \%$ heading.

The data collected were subjected to analysis of variance using the CoStat 6.3 software (CoHort Software, Monterey, CA, USA) to determine significance of the tested factors (cultivar, sulphur and nitrogen levels) and their interactions with sorghum traits. Means of significant effects were separated using the test at 5\% level of significance.

\section{RESULTS AND DISCUSSION}

\section{Hydrocyanic acid content}

Hydrocyanic acid $(\mathrm{HCN})$ content was observed in sorghum cultivars and results showed a significant 
difference (Table 1). The Chakwal sorghum produced the highest HCN content (22.6 and $15 \mathrm{mg} / 100 \mathrm{~g})$ while the lowest was 11.5 and $9.0 \mathrm{mg} / 100 \mathrm{~g}$ by JS-2002 cultivar at booting and $50 \%$ heading stage, respectively. From the data, it appeared that $27-40 \%$ less HCN content was found in Js-2002 when compared with Chakwal sorghum at respective growth stages. The difference of $\mathrm{HCN}$ content may be due to the genetic makeup of different sorghum cultivars and climatic condition during the crop growth period at different years. The results are in agreement with findings of Hanuman et al. (2008) who reported that HCN content variation may depend on their genetic makeup of cultivars. Abusuwar and Hala (2010), Pandey et al. (2011), Sarfraz et al. (2012) and Sher et al. (2012) found higher HCN content in Abu Sabein, hybrid variety, Hegari and local sorghum, respectively than the other varieties. In our findings, Chakwal sorghum produced higher $\mathrm{HCN}$ content as compared with JS-2002. This decrease in HCN contents might be due to more green forage yield (data not shown) and sugar content.

Table 1. Interactive effect of Cultivar, Sulphur and Nitrogen application on hydrocyanic acid content (HCN) of sorghum forage in URF during summer 2008, 2009 and 2010

\begin{tabular}{|c|c|c|}
\hline Treatments & Growth s & \\
\hline & Booting & 50\% heading \\
\hline Cultivars (C) & & \\
\hline JS-2002 & $16.5 \mathrm{~b}$ & $9.0 \mathrm{~b}$ \\
\hline Chakwal sorghum & $22.6 \mathrm{a}$ & $15.0 \mathrm{a}$ \\
\hline$P$ & $<0.001 * *$ & $<0.001 * *$ \\
\hline Sulphur Levels (S; & & \\
\hline 0 & $28.4 \mathrm{a}$ & $17.1 \mathrm{a}$ \\
\hline 20 & $17.9 \mathrm{~b}$ & $11.0 \mathrm{~b}$ \\
\hline 40 & $12.3 \mathrm{c}$ & $8.0 \mathrm{c}$ \\
\hline$P$ & $<0.001 * *$ & $<0.001 *$ \\
\hline Nitrogen Levels (N & & \\
\hline 0 & $17.8 \mathrm{c}$ & $11.0 \mathrm{c}$ \\
\hline 60 & $19.3 \mathrm{~b}$ & $11.7 \mathrm{~b}$ \\
\hline 120 & $21.5 \mathrm{a}$ & $13.4 \mathrm{a}$ \\
\hline$P$ & $<0.001 * *$ & $<0.001 * *$ \\
\hline Year $(Y)$ & & \\
\hline 2008 & $19.6 \mathrm{~b}$ & $11.9 \mathrm{~b}$ \\
\hline 2009 & $21.9 \mathrm{a}$ & $13.1 \mathrm{a}$ \\
\hline 2010 & $17.2 \mathrm{c}$ & $11.0 \mathrm{c}$ \\
\hline$P$ & $<0.001 * *$ & $<0.001 * *$ \\
\hline $\mathbf{C} \times \mathbf{S}$ & & \\
\hline$P$ & $1.00 \mathrm{~ns}$ & $1.00 \mathrm{~ns}$ \\
\hline $\mathbf{C} \times \mathbf{N}$ & & \\
\hline$P$ & $1.00 \mathrm{~ns}$ & $1.00 \mathrm{~ns}$ \\
\hline $\mathbf{S} \times \mathbf{N}$ & & \\
\hline$P$ & $<0.001 * *$ & $<0.001 * *$ \\
\hline $\mathbf{C} \times \mathbf{S} \times \mathbf{N}$ & & \\
\hline$P$ & $1.00 \mathrm{~ns}$ & $1.00 \mathrm{~ns}$ \\
\hline $\mathbf{C} \times \mathbf{Y}$ & & \\
\hline$P$ & $0.164 \mathrm{~ns}$ & $0.748 \mathrm{~ns}$ \\
\hline $\mathbf{S} \times \mathbf{Y}$ & & \\
\hline$P$ & $0.448 \mathrm{~ns}$ & $0.605 \mathrm{~ns}$ \\
\hline $\mathbf{C} \times \mathbf{S} \times \mathbf{Y}$ & & \\
\hline$P$ & $1.00 \mathrm{~ns}$ & $1.00 \mathrm{~ns}$ \\
\hline $\mathbf{N} \times \mathbf{Y}$ & & \\
\hline$P$ & $0.981 \mathrm{~ns}$ & $0.995 \mathrm{~ns}$ \\
\hline $\mathbf{C} \times \mathbf{N} \times \mathbf{Y}$ & & \\
\hline$P$ & $1.00 \mathrm{~ns}$ & $1.00 \mathrm{~ns}$ \\
\hline $\mathbf{S} \times \mathbf{N} \times \mathbf{Y}$ & & \\
\hline$P$ & $0.999 \mathrm{~ns}$ & $0.992 \mathrm{~ns}$ \\
\hline $\mathbf{C} \times \mathbf{S} \times \mathbf{N} \times \mathbf{Y}$ & & \\
\hline$P$ & $1.00 \mathrm{~ns}$ & $1.00 \mathrm{~ns}$ \\
\hline C.V. (\%) & 9.9 & 14.4 \\
\hline
\end{tabular}

ns, $* * *$ mean non-significant, significant at $P \leq 0.05$ and $P \leq 0.01$, respectively

Different letters indicate significantly-different means (SNK test; $P \leq 0.05$ ) 
Regardless to cultivars, increase in sulphur levels reduced the HCN content. Minimum HCN content of 12.3 and $8.0 \mathrm{mg} / 100 \mathrm{~g}$ was recorded with the application of 40 $\mathrm{kg} \mathrm{S} \mathrm{ha}{ }^{-1}$ whereas maximum was 28.4 and $17.1 \mathrm{mg} / 100 \mathrm{~g}$ in control plot at booting and $50 \%$ heading stage, respectively. The increase rate of sulphur resulted is 53$57 \%$ less HCN content in comparison with control plots. The reason might be the sulphur as an important component of chlorophyll, amino acids, enzymes and seed formation (Sharma, 1991).

With the increase in nitrogen fertilizer $\mathrm{HCN}$ content also gradually increased in sorghum plants (Table 1). Fertilizing sorghum forage with $120 \mathrm{~kg} \mathrm{~N} \mathrm{ha}^{-1}$ produced the highest $\mathrm{HCN}$ content (21.5 and $13.4 \mathrm{mg} / 100 \mathrm{~g})$ at booting and $50 \%$ heading stage, respectively while the lowest $\mathrm{HCN}$ content of 17.8 and $11.0 \mathrm{mg} / 100 \mathrm{~g}$ was recorded in control treatment where no fertilizer was applied. The increase of HCN content (21-22\%) was more with the application of $120 \mathrm{~kg} \mathrm{~N} \mathrm{ha}^{-1}$ when compared with control treatment $\left(0 \mathrm{~kg} \mathrm{~N}\right.$ ha $\left.^{-1}\right)$. No doubt $\mathrm{N}$ is an important component for plant growth and development (Shehu et al., 2010). In sorghum plant increase in $\mathrm{N}$ level significantly increased $\mathrm{HCN}$ content which can be harmful, therefore it is important to explore the genetic source of sorghum which has less $\mathrm{HCN}$ trigger towards high $\mathrm{N}$ application. The similar results have been reported by Sher et al. (2012) that with the application of @ $120 \mathrm{~kg}$ $\mathrm{N} \mathrm{ha}^{-1}$ produced $64 \%$ more $\mathrm{HCN}$ content than control plot. Bahrani and Ghenateghestani (2004) also reported an increase of $55 \%$ higher $\mathrm{HCN}$ content with nitrogen application in forage sorghum.

Seasonal variations produced minimum $\mathrm{HCN}$ content of $17.2 \& 11.0 \mathrm{mg} / 100 \mathrm{~g}$ during 2010 as compared to 2009 probably as result of higher seasonal rainfall. A reduction of 22 and $16 \%$ less HCN content was recorded during 2010 than 2009 at booting and 50\% heading stage, respectively. In our experiments the $\mathrm{HCN}$ content does not exceed the safe limit during entire crop growth duration. The toxin (HCN) can exceed the safe limit (>200 $\mathrm{mg} \mathrm{kg}^{-1}$ ) if animals are fed for long time on the pre- mature stages and forage produced under low rainfall conditions (Sher et al., 2012).

Significant interaction of sulphur and nitrogen application was observed at both growth stages (booting \& 50\% heading) during three years of study (Figure 2). Maximum $\mathrm{HCN}$ content of 31.9 and $19 \mathrm{mg} / 100 \mathrm{~g}$ was recorded with the application of $120 \mathrm{~kg} \mathrm{~N} \mathrm{ha}^{-1}$ and in control plots where no sulphur was applied at respective growth stages, respectively.

\section{Brix value (\%fresh stalk)}

Brix value is an important characteristic to determine the forage quality. Significantly differences were recorded in the brix value of forage sorghum cultivars exposed to varying nitrogen and sulphur applications grown under subtropical rainfed regions during 2008 to 2010 (Table 2). Sorghum cultivar JS-2002 produced highest brix value of 13.3 and $23 \%$ whereas Chakwal sorghum resulted lowest brix value of 11.3 and $21.3 \%$ at booting and $50 \%$ heading stage, respectively. The results indicated 8 and $18 \%$ higher brix value in JS-2002 than Chakwal sorghum at booting and $50 \%$ heading stage, respectively. Mahammed and Moataz (2009) found a significant difference of brix value among different genotypes. Similarly, Almodares et al., (2007) reported that the difference of brix value might be due to genetic variability and stem thickness. Present work indicated that sorghum cultivar JS-2002 produced highest brix value than Chakwal sorghum.

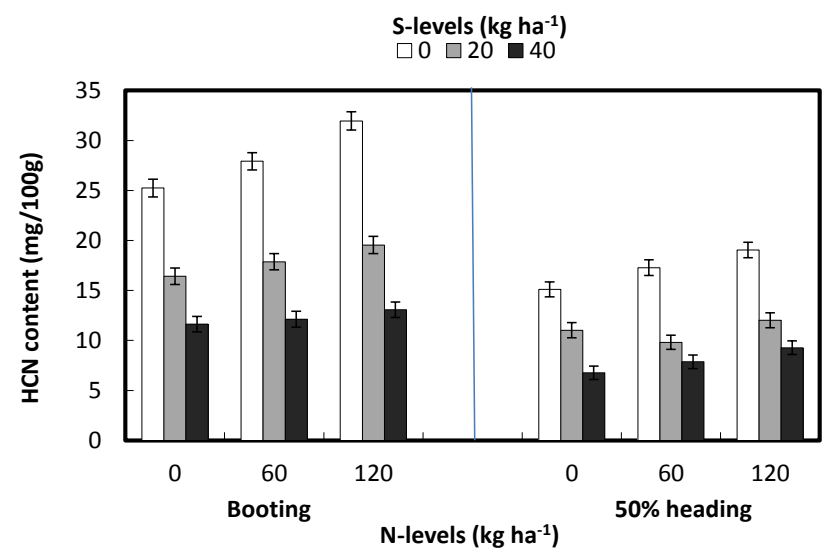

Figure 2. Effect of nitrogen and sulphur levels interaction on hydrocyanic acid content $(\mathrm{HCN})$ at booting and $50 \%$ heading stage. Error bars represent the standard error $(n=5)$.

Increasing sulphur application progressively increased brix value of forage sorghum cultivars throughout the experimentation period under field conditions. Higher brix value of 13.3 and $23.8 \%$ was recorded with the application of $40 \mathrm{~kg} \mathrm{~S} \mathrm{ha}^{-1}$ while lower (11.5 and $20.5 \%$ ) in control treatment at respective growth stages, clearly indicating the positive affect of $\mathrm{S}$ application on forage sorghum. Regardless to sulphur, the highest brix value of 15 and $27.3 \%$ was observed with the application of $120 \mathrm{~kg} \mathrm{~N} \mathrm{ha}^{-1}$, which produced $56-59 \%$ higher brix value at booting and $50 \%$ heading stage, respectively than control treatment (9.6 and $17.2 \%$ ) where no $\mathrm{N}$ was applied. Pholsen and Sukrsi (2007) found a range of brix value between 11 and $12.5 \%$ at $\mathrm{N}-\mathrm{K}_{2} \mathrm{O}$ rates. In our experiment, an average range of brix value (9.6 to $27.3 \%$ ) was recorded at different nitrogen levels during study period. In contrast Almodares et al., (2007, 2008) found no significant difference with the application of different nitrogen levels on brix value.

Seasonal variations produced maximum sugar content of $14.9,25.6 \%$ at booting and $50 \%$ heading stage during 2010 as compared to 2009 , respectively probably as result of seasonal rainfall variation as depicted in Figure 1. 
Table 2. Interactive effect of Cultivar, Sulphur and Nitrogen application on brix value of sorghum forage in URF during summer 2008, 2009 and 2010

\begin{tabular}{|c|c|c|}
\hline \multirow[t]{2}{*}{ Treatments } & \multicolumn{2}{|c|}{ Growth stages } \\
\hline & Booting & 50\% heading \\
\hline \multicolumn{3}{|l|}{ Cultivars (C) } \\
\hline JS-2002 & $13.3 \mathrm{a}$ & $23.0 \mathrm{a}$ \\
\hline Chakwal sorghum & $11.3 \mathrm{~b}$ & $21.3 \mathrm{~b}$ \\
\hline$P$ & $<0.001 * *$ & $<0.001 * *$ \\
\hline \multicolumn{3}{|c|}{ Sulphur Levels (S; Kg ha ${ }^{-1}$ ) } \\
\hline 0 & $11.5 \mathrm{c}$ & $20.5 \mathrm{c}$ \\
\hline 20 & $12.1 \mathrm{~b}$ & $22.2 \mathrm{~b}$ \\
\hline 40 & $13.2 \mathrm{a}$ & $23.8 \mathrm{a}$ \\
\hline$P$ & $<0.001 * *$ & $<0.001 *$ \\
\hline \multicolumn{3}{|c|}{ Nitrogen Levels ( $\left.\mathbf{N} ; \mathrm{Kg} \mathrm{ha}^{-1}\right)$} \\
\hline 0 & $9.6 \mathrm{c}$ & $17.2 \mathrm{c}$ \\
\hline 60 & $12.1 \mathrm{~b}$ & $22.0 \mathrm{~b}$ \\
\hline 120 & $15.0 \mathrm{a}$ & $27.3 \mathrm{a}$ \\
\hline$P$ & $<0.001 * *$ & $<0.001 * *$ \\
\hline \multicolumn{3}{|l|}{ Year (Y) } \\
\hline 2008 & $13.1 \mathrm{~b}$ & $23.1 \mathrm{~b}$ \\
\hline 2009 & $8.8 \mathrm{c}$ & $17.7 \mathrm{c}$ \\
\hline 2010 & $14.9 \mathrm{a}$ & $25.6 \mathrm{a}$ \\
\hline$P$ & $<0.001 * *$ & $<0.001 * *$ \\
\hline \multicolumn{3}{|l|}{$\mathbf{C} \times \mathbf{S}$} \\
\hline$P$ & $0.800 \mathrm{~ns}$ & $0.264 \mathrm{~ns}$ \\
\hline \multicolumn{3}{|l|}{$\mathbf{C} \times \mathbf{N}$} \\
\hline$P$ & $<0.046^{*}$ & $0.544 \mathrm{~ns}$ \\
\hline \multicolumn{3}{|l|}{$\mathbf{S} \times \mathbf{N}$} \\
\hline$P$ & $0.167 \mathrm{~ns}$ & $0.106 \mathrm{~ns}$ \\
\hline \multicolumn{3}{|l|}{$\mathrm{C} \times \mathrm{S} \times \mathrm{N}$} \\
\hline$P$ & $0.616 \mathrm{~ns}$ & $0.288 \mathrm{~ns}$ \\
\hline \multicolumn{3}{|l|}{$\mathbf{C} \times \mathbf{Y}$} \\
\hline$P$ & $<0.017 *$ & $<0.002 *$ \\
\hline \multicolumn{3}{|l|}{$\mathbf{S} \times \mathbf{Y}$} \\
\hline$P$ & $<0.021 *$ & $<0.022 *$ \\
\hline \multicolumn{3}{|l|}{$\mathbf{C} \times \mathbf{S} \times \mathbf{Y}$} \\
\hline$P$ & $0.717 \mathrm{~ns}$ & $0.827 \mathrm{~ns}$ \\
\hline \multicolumn{3}{|l|}{$\mathbf{N} \times \mathbf{Y}$} \\
\hline$P$ & $<0.001 * *$ & $<0.001 * *$ \\
\hline \multicolumn{3}{|l|}{$\mathbf{C} \times \mathbf{N} \times \mathbf{Y}$} \\
\hline$P$ & $0.672 \mathrm{~ns}$ & $0.184 \mathrm{~ns}$ \\
\hline \multicolumn{3}{|l|}{$\mathbf{S} \times \mathbf{N} \times \mathbf{Y}$} \\
\hline$P$ & $0.370 \mathrm{~ns}$ & $<0.047^{*}$ \\
\hline \multicolumn{3}{|l|}{$\mathbf{C} \times \mathbf{S} \times \mathbf{N} \times \mathbf{Y}$} \\
\hline$P$ & $0.685 \mathrm{~ns}$ & $0.968 \mathrm{~ns}$ \\
\hline C.V. $(\%)$ & 8.7 & 5.1 \\
\hline
\end{tabular}

ns, *,** mean non-significant, significant at $P \leq 0.05$ and $P \leq 0.01$, respectively

Different letters indicate significantly-different means (SNK test; $P \leq 0.05$ )

Interaction between cultivar and nitrogen levels showed statistically significance difference in brix values at booting stage (Figure 3) while 50\% heading stage remained non-significant. Maximum brix value $16.2 \%$ was recorded by JS-2002 with $120 \mathrm{~kg} \mathrm{ha}^{-1}$ nitrogen fertilizer application while minimum was $8.8 \%$ in Chakwal Sorghum where no nitrogen was made. Significant interaction of $\mathrm{C} \times \mathrm{Y}, \mathrm{S} \times \mathrm{Y}$ and $\mathrm{N} \times \mathrm{Y}$ were also found to be significantly different at booting and $50 \%$ heading stages (Figure 4.a, b, c). During 2010, the highest brix value of 16.1 and $26.7 \%$ was observed in JS-2002 while the lowest 8.1 and $17.4 \%$ was in Chakwal sorghum during 2009. Similarly, the highest brix value of 16.2 and $27.6 \%$ and 18.2 and $31.8 \%$ was recorded where sulphur and nitrogen were applied @ 40 and $60 \mathrm{~kg} \mathrm{ha}^{-1}$ in 2010. Interactive effect of $\mathrm{S} \times \mathrm{N} \times \mathrm{Y}$ was found maximum brix value of $34.3 \%$ was recorded when sulphur and nitrogen was applied @ 40 and $60 \mathrm{~kg} \mathrm{ha}^{-1}$, respectively during the year 2010 while minimum $13.5 \%$ was in control plots of both nutrients in 2009 (Figure 5). 


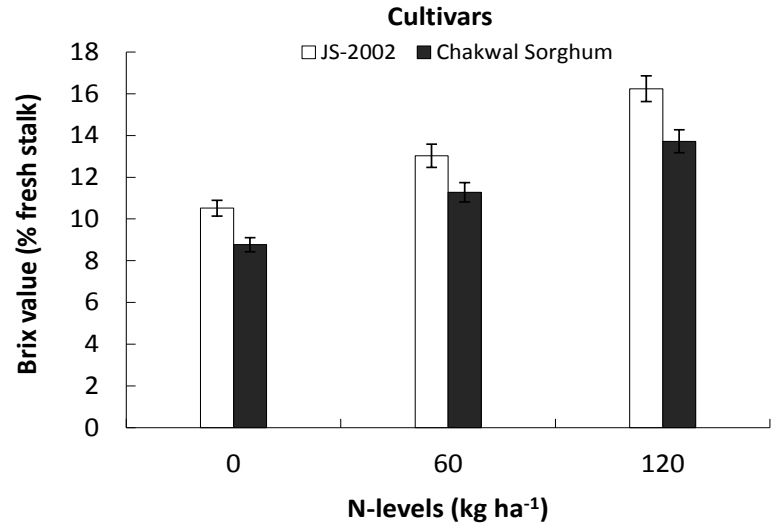

Figure 3. Effect of cultivar and nitrogen levels interaction on brix value (\% fresh stalk) at booting stage. Error bars represent the standard error $(\mathrm{n}=5)$.
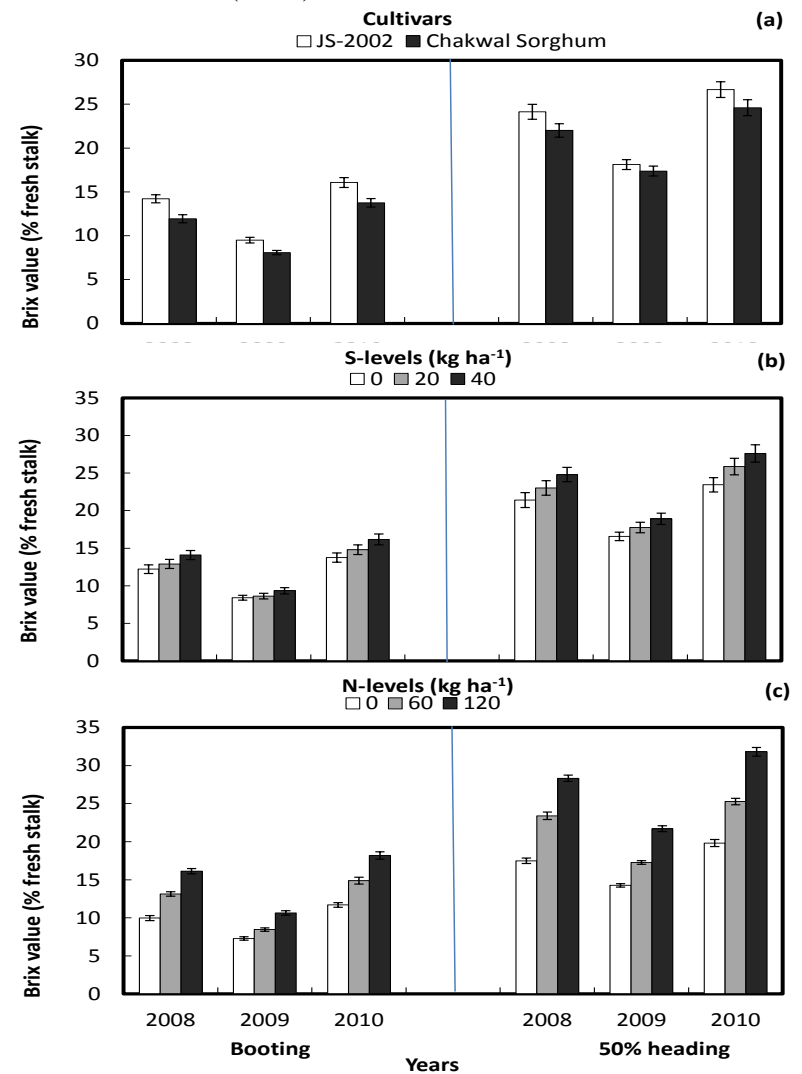

Figure 4. Effect of cultivar, sulphur and nitrogen levels interaction on brix value (\% fresh stalk) at booting and 50\% heading stage during 2008, 2009 and 2010. Error bars represent the standard error $(\mathrm{n}=5)$.

\section{CONCLUSIONS}

The finding of three year field investigations clearly demonstrated that increased application of $\mathrm{N}$ resulted in increased content of $\mathrm{HCN}$ and brix in the forage sorghum. Therefore there is a need to explore sorghum genetic source which can result higher green forage yield with low $\mathrm{HCN}$ content. The application of S increased contents of brix while reduced the $\mathrm{HCN}$ content irrespective of sorghum cultivars. Therefore, our research work is a step towards investigation to explore balanced $\mathrm{N}$ and $\mathrm{S}$ fertilization ratio for reduced $\mathrm{HCN}$ content and increased sugar content in sorghum either for livestock or milling for industrial purposes.

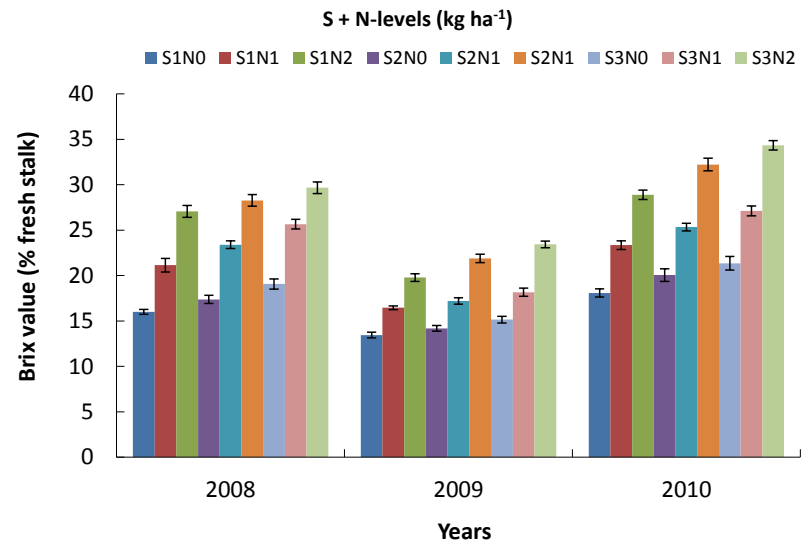

Figure 5. Effect of nitrogen and sulphur levels interaction on brix value (\% fresh stalk) at $50 \%$ heading stage during three consecutive years $(2008,2009 \& 2010)$. Error bars represent the standard error $(n=5)$.

\section{LITERATURE CITED}

Abusuwar, A.O. and Hala AEl-Zilal. 2010. Effect of chicken manure on yield, quality and $\mathrm{HCN}$ concentration of two forage Sorghum (Sorghum bicolor (L) Moench) cultivars. Agric and Biol. J. North America. Pp. 27-31.

Almodares, A., M.R. Hadi, M. Ranjbar and R. Taheri. 2007. The effects of nitrogen treatments, cultivars and harvest stages on stalk yield and sugar content in sweet sorghum. Asian J. Plant Sci. 6(2): 423-426.

Almodares, A., R. Taheri, I.M. Chung and M. Fathi. 2008. The effect of nitrogen and potassium fertilizers on growth parameters and carbohydrate contents of sweet sorghum cultivars. J. Environ. Biol. 29(6): 849-852.

Aziz-Abdel, T.K. and M.A.S. Abdel-Gwad. 2008. Yield and quality of tunis grass as affected by plant height at cutting and $\mathrm{N}$ fertilizer. Animal Agric. Sci. (Cairo). Pp. 157-169.

Bahrani, M.J. and A.D. Ghenateghestani. 2004. Summer forage sorghum yield, protein and prussic acid contents as affected by plant density and nitrogen top dressing. J. Agric. Sci. Tech. Pp. 73-83.

Bradbury, G.M., S.V. Egan and J.H. Bradbury. 1999. Picrate paper kits for determination of total cyanogens in cassava roots and all forms of cyanogens in cassava products. J. Sci. Food Agric. Pp. 593-601.

Chaubey, A.K., K.N. Dwivedi and R.S. Yadav. 1992. Effect of N, P and S on linseed. J. Ind. Soc. Soil Sci. 40: 758-761.

Duli, Z.K., V.R. Reddy, G. Kakani and V.R. Reddy. 2005. Nitrogen deficiency effects on plant growth, leaf photosynthesis and hyper spectral reflectance properties of sorghum. Europ J. Agron. 22: 391-403.

Fjell, D., B. Dale and T. Gene. 1991. Nitrate and prussic acid toxicity in forage causes, prevention and feeding management, pp: 1-4. Cooperative extension service, Kansas state university, Manhattan, Kansas, USA.

Hallmark, W.B. and L.P. Brown. 1994. Interactive effects of sulphur and potassium fertilization on Bermuda grass hay yields. Sulphur Agric. 18: 41-44.

Hanuman, S., S. Pushpendra and H.K. Sumerhya. 2008. Effect of fertility levels on fodder yield and HCN content of fodder sorghum (Sorghum bicolor (L) Moench) genotypes. Inter J. Tropical Agri. Pp. 417-420. 
Lang, B. 2001. Sudan/sorghum forage management. Iowa state University.

Mohammed, M.I. and M.A. Moataz. 2009. Evaluation of newly developed sweet sorghum (Sorghum bicolor) genotypes for some forage attributes. American-Eurasian J. Agric. Environ. Sci. 6(4): 434-440.

Pandey, R.K., D. Kumar and K.M. Jadhav. 2011. Assessment of determinants for reducing HCN content in sorghum used for ruminant in Gujarat, India. Livestock Res. Rural Development. 23 (3), Article \#66

Parvatikar, S.R. and T.V. Manjunath. 1991. Alternate uses of sweet sorghum, a new prospectus for juicy stalks and grain yields. J. Maharashtra Agric. 16: 352-354.

Pederson, G.A., T.E. Fairbrother and S.L. Greene. 1996. Cyanogenesis and climatic relationships in U.S. white clover germplasm collection and core subset. Crop Sci. Pp. 427433.

Pholsen, S. and N. Somsungnoen. 2004. Effect of nitrogen and potassium rates and planting distances on growth, yield and fodder quality of a forage sorghum (Sorghum bicolor L. Moench). Pak. J. Bio. Sci. 7(10): 1793-1800.

Pholsen, S. and A. Suksri. 2007. Effect of phosphorus and potassium on growth, yield and fodder quality of IS 23585 forage sorghum cultivar (Sorghum bicolor L. Moench). Pak. J. Bio. Sci. 10(10): 1604-1610.

Platou, J.S. and R. Irish. 1982. The fourth major nutrient. The Sulfur Institute, Washington, DC.

Puoli, J.R., G.A. Jung and R.L. Reid. 1991. Effects of nitrogen and sulphur on digestion and nutritive quality of warmseason grass hays for cattle and sheep. J. Anim. Sci. 69: 843852.
Reddy, B.V.S., S. Ramesh and P.S. Reddy. 2004. Sorghum breeding research at ICRISAT- goals, strategies, methods and accomplishments. International Sorghum and Millets Newsletter 45, 5-12.

Saraswathy, R., S. Suganya and P. Singaram. 2007. Environmental impact of nitrogen fertilization in tea ecosystem. J. Environ. Biol. 28: 779-788.

Sarfraz, M., N. Ahmad, U. Farooq, A. Ali and K. Hussain. 2012. Evaluation of sorghum varieties/lines for hydrocyanic acid and crude protein contents. J. Agric. Res. Pp. 39-47.

Schnug, E. and S. Haneklaus. 1993. Impact of sulphur fertilization on fertilizer nitrogen efficiency. Sulphur Agric. 17: 8-12.

Sharma, B.K. 1991. Industrial chemistry. Krishna Prakashan. Goel publishing house Meerut.

Shehu, H.E., C.S. Ezekiel, J.D. Kwari and M.K. Sandabe. 2010. Agronomic Efficiency of N, P and K Fertilization in sesame (Sesamum indicum) in Mubi Region, Adamawa State, Nigeria. Nature and science. 8(8): 257-260.

Sher, A., M. Ansar, F.U. Hassan, G. Shabbir and M.A. Malik. 2012. Hydrocyanic acid contents variation amongst sorghum cultivars grown with varying seed rates and nitrogen levels. Int. J. Agric. Biol. 14: 720-726.

Tsialtas, J.T. and N. Maslaris. 2005. Effect of N fertilization rate on sugar yield and non-sugar impurities of sugar beets (Beta vulgaris) grown under Mediterranean conditions. J. Agron. Crop Sci. 191: 330-339.

Yun-long, B., Y. Seiji, I. Maiko and C. Hong-Wei. 2006. QTLs for sugar contents of stalks in sweet sorghum (Sorghum bicolor L. Moench). Agric. Sci. China. 5(10): 736-744. 